\title{
PAPER-MAKING APPARATUS AT THE MANCHESTER COLLEGE OF SCIENCE AND TECHNOLOGY
}

$\mathrm{T}$ HE Paper-Making Section of the Textile Chemistry Department of the Manchester College of Science and Technology has been given laboratory equipment worth $£ 5,000$ by the Reed Paper Group. Mr. T. E. G. Baker, a director of Albert E. Reed and Co., Ltd., handed over the apparatus officially on October 24. The gift was received by Dr. B. Y. Bowden, principal of the College, at a small ceremony attended by representatives of the Northern District of the British Paper and Board Makers' Association, executives of the Reed Paper Group and members of the College staff.

Although classes in paper technology were held in the Mechanics Institute, which preceded the College, they received their first big impetus in 1903 when the newly founded Municipal School of Technology acquired a demonstration paper machine $24 \mathrm{in}$. wide, and set it up in the new dyehouse. This fifty-year old machine is still put to good use for teaching and research. In 1905 the Faculty of Technology in the University of Manchester was instituted, and it then became possible for students in the Department of Applied Chemistry to take paper manufacture as a principal subject when studying for the degree of B.Sc. Tech. The Paper Technology Section later became part of the Department of Textile Chemistry, in which Dr. R. H. Peters was appointed to the first chair in 1955. The University approved the institution of an honours degree course in paper technology in 1954, and the first students taking this revised course obtained their degrees in the summer of 1956. The new degree course is based mainly on physics, to meet the current requirements of the industry. The course was designed by the late Dr. W. W. Barkas, who was appointed senior lecturer in paper technology in 1949 but died at the early age of fifty-six in 1955. The previous senior lecturer, $\mathrm{Mr}$. F. W. Bailey, retired in 1949 after nearly twenty-five years at the College. He was a very welcome guest at the presentation of the new apparatus.

In 1954 the Northern District of the British Paper and Board Makers' Association instituted a scholarship fund, and since 1955 seven George Rackley scholarships have been awarded to full-time students reading for degrees. These scholarships have had more effect than might be expected, as in addition to the Rackley scholars other students have joined the Department, with local authority grants. Research students have always been encouraged, and a new postgraduate diploma course has just been instituted for those who wish to atudy paper technology for one year only. At present thero are twenty full-tirne students in the section and, in addition, ten parttime students taking evening and part-time day classes.

The new equipment includes a Wennberg electrically heated rotating autoclave specially designed for making paper pulp on the pilot scale. This can be used either for demonstrations with regular raw materials such as wood, cotton rags or straw, or for research on any vegetable raw material. It will treat about $2 \mathrm{kgm}$. at a time. A disintegrator and strainer on the same scale are used for breaking up the pulp and removing uncleared fibre bundles.
'Beating' is the main mystery of paper making. The cellulose fibres suspended in water are passed between bars (usually bronze), which are rubbed together under considerable pressure. It is not easy to design a beater which will do this really well in the laboratory, as stock does not circulate properly in scale models of conventional beaters at the correct solids content. The Reed Group has given the College a 'Medway' beater designed in its laboratories. Though unlike a commercial beater in appearance, it will work over a wide range of operating conditions and is particularly suitable for demonstration and research.

The 'substance' (area-density) of paper is its most important property and has always been checked during manufacture by tearing out samples at intervals and weighing thern; this necessitates joins in the reels. Substance is now controlled by beta-ray gauges in which the permeability of the paper to beta-rays from a thallium source is measured in a suitable apparatus. The gift includes a Baldwin 'Atornat' apparatus which is to be fitted on the College machine. By measuring substance at both ends of the machine, the water content at the wet end can be estimated.

A low $p \mathrm{H}$ in paper is bad for its permanence, and a high $p H$ is detrimental to sizing. The control of $p \mathrm{HI}$ is, therefore, important, and the apparatus includes an EIL $p H$ meter which can be coupled to Honeywell-Brown recording and control instruments. The control system can be used, altornatively, for controlling temporatures and pressures and will be useful for demonstrating the principles of controllers to students.

The Van de Korput dynamic tensile tester measures the work done in breaking paper by applied tension. It correlates better with practical behaviour than conventional tensile testers. The Somerville fractionater is used for separating paper pulps into fractions of different fibre-length, and can also be used for straining. The study of coatings for paper is increasingly important, and the gift includes a Ferranti viscometer for checking the apparenviscosity and investigating the flow of these suspent sions. F. L. Hudson

\section{AGRICULTURAL POLICIES IN EUROPE AND NORTH AMERICA}

$\mathrm{T}$ HE Organization for European Economic Cooperation has issued an interesting report on agricultural policies in all European countries except the U.S.S.R. and its satellites, and also in Canada and the United States*. The picture is on the whole reassuring. In Europe the population has been increasing at the rate of about 1 per cent per annum, but the agricultural output has risen

* Agricultural Policies in Europe and North America-First Report of the Ministerial Committee for Agriculture and Food. May 1952 3 dollars; $900 \mathrm{fr}$. 
by 4 per cent per annum since 1949/50. Food consumption per head has increased because of higher purchasing power; real income per head has during the past four years increased by $2 \cdot 75$ per cent per annum, and about half of this is spent in food.

The policies in the various countries have had the common aim of increasing agricultural output with the single exception of Sweden, where the present output of 107 per cent of domestic food requirements is to be reduced to 90 per cent. Planning has been generally abandoned; there are no longer targets for individual commodities as during the Second World War. What mostly happens now is that farmers are exhorted to produce all they can. A few countries have over-all targets : Great Britain is aiming at 60 per cont increased output over pre-war and has already achieved 56 per cent.

Germany has made the most remarkable recovery. During 1948-49 the agricultural output was nearly 30 per cent below pre-war; during 1954-55 it was 23 per cent above pre-war and was providing 70-75 per cent of the total food requirements in spite of the fact that the agricultural area per head had fallen by nearly one-third in consequence of the flow of refugees from Eastern Germany. There are no specific regulations-only a general requirement that food output must be as large as possible. Of the European exporters of food, Denmark, two-thirds of the export earnings of which are derived from food, aims at improved quality and higher degree of processing so as to increase the value per ton, rather than increasing the number of tons produced. The Netherlands have only the general aim of making agriculture contribute as much as possible to the national wealth : the exports include about 25 per cent of the crop output, 40 per cent of animal produc. tion and more than $\tilde{5} 0$ per cent of horticultural production. In 1954, the total value of these exports was nearly 900 thousand dollars; but.against this was an import of feeding stuffs, other agricultural commodities and human food amounting to 650 thousand dollars. Switzerland and the Irish Republic are among the few countries with a declared demographic aim : both desire to organize their agriculture in such a way as to maintain a large peasant popula. tion.

\section{SIXTH INTERNATIONAL CONGRESS OF SOIL SCIENCE}

$\mathrm{T}$ HE Sixth International Congress of Soil Science, organized by the International Society of Soil Science, was held in Paris at the Maison de la Chimie during August 29-September 8, under the presidency of A. Oudin, Inspecteur Général des Eaux et Forêts, France. The Congress was divided into six commissions, the chairmen of which were as follows: Dr. M. B. Ruszel (United States), physics; Dr. A. C. Schuffelen (Holland), chemistry; Dr. P. Simonart (Belgium), biology ; Dr. E. W. Russell (East Africa), fertility ; Dr. A. Muir (Great Britain), classification; and Dr. J. V. Botelho Da Costa (Portugal), soil technology. The Congress attracted the largest number of members, the enrolment being 850 representing fifty countries, as compared with the two previous congresses in Amsterdam and Léopoldville (Congo), where the attendances were 600 and 250 , respectively.
Naturally, the largest group was from France, the next biggest groups being Great Britain, Belgium and the Congo, Holland, West Germany, United States, Spain, Italy, the U.S.S.R., Yugoslavia, East Germany and Switzerland.

The six hundred papers presented at the Congress, most of which were available in printed form, making four separate volumes, covered a wide field of prob. lems, the most important being the influence of climate on soils, soil structure, soil colloids, acid soils, saline and alkali soils and their reclamation, phosphate and potash contents and nutrition, nitrogen transformations, soil micro-organisms, symbiotic, nonsymbiotic, photochemical nitrogen fixation, trace (oligo) elements, forest soils and desert soils. Each author was given a quarter of an hour for outlining his contribution, followed by a discussion lasting 15-20 minutes.

In the afternoon of September 1 there was an interesting colloquium on fertilization and production of paddy, in which several soil scientists from Japan, China, India, the Congo and other tropical parts of the world took active part. A session on the morning of September 8 was devoted to a colloquium on the physico-chemical aspects of mineral nutrition by the plant roots. Some interesting papers were read; but there was no general unanimity of views regarding the mechanism of this process in crop production. As a side-issue of the Congress, there was an important colloquium on leaf analysis and plant nutrient supply, organized by Dr. P. Preaud, in which an introductory paper by Prof. T. Wallace was read.

Dr. Bruin, of Holland, put forward the proposal that soil scientists hailing from temperate countries should co-operate in obtaining accurate data on the influence of nitrogenous fertilizers in crop production, and he arranged the convening of a meeting for this purpose in Groningen in November. It is well known that nitrogenous fertilizers are not much used in Asiatic countries, where the majority of the human beings of the world subsist. Moreover, only 3 per cent of the world crop yield has been attributed to artificial nitrogenous fertilizers, as reported at the meeting of the British Association in 1949 in Newcastle (see Nature, 164, 597; 1949): "At present only some three per cent of the world food production can be attributed to the use of nitrogenous fertilizers. To raise the available food by ten per cent, that is to say, one hundred million tons, involves a fourfold increase in supplies of fixed nitrogen, at an approximate capital cost of $£ 1,500,000,000$. This ... would take a minimum of 15 years to achieve". Hence, even to-day world food production has to be mainly attributed to the soil nitrogen present in the soil organic matter or humus, the study of which from different angles attracted the attention of a large number of mombers of the Congress.

On September 7 there was a whole-day excursion for the study of soil profiles and other topics of agricultural importance in the Paris area. After the Congress, excursions lasting a week were made in different parts of France for the study of soils. In addition, on September 2 several members were taken around the National Agricultural Research Institute at Versailles, and the following week a group visited the Institute at Bondy, $20 \mathrm{~km}$. from Paris, for training French soil scientists for work in the Colonies and research work on problems of Colonial agriculture. 